\title{
GAMBARAN KEBIASAAN MENGONSUMSI MAKANAN CEPAT SAJI DAN OBESITAS PADA MAHASISWA SEMESTER V PROGRAM STUDI KEDOKTERAN UMUM \\ UNIVERSITAS UDAYANA TAHUN 2014
}

\section{Tjokorda Istri Ratih Pradnyandari Pemayun ${ }^{1}$, I Made Ratna Saraswati²}

Program Studi Pendidikan Dokter Fakultas Kedokteran Universitas Udayana ${ }^{1}$

Bagian/SMF Ilmu Penyakit Dalam Fakultas Kedokteran Universitas Udayana RSUP Sanglah Denpasar ${ }^{2}$

\begin{abstract}
ABSTRAK
Latar belakang : Obesitas terjadi karena kelebihan lemak yang ditimbun dalam jaringan subkutan dan intra abdominal. Prevalensi obesitas di dunia sekitar 300 juta orang. Prevalensi obesitas pada wanita di Indonesia yaitu $32,9 \%$ dan laki-laki $19,7 \%$. Prevalensi obesitas pada dewasa usia 18 tahun adalah $15,4 \%$. Faktor risiko utama timbulnya obesitas adalah perubahan pola makan termasuk kebiasaan mengkonsumsi makanan cepat saji.

Tujuan penelitian : mengetahui gambaran kebiasaan mengkonsumsi makanan cepat saji dan obesitas pada mahasiswa Kedokteran.

Metodologi penelitian : Penelitian ini adalah deksriptif cross sectional. Responden penelitian yaitu 127 mahasiswa semester V FK Umum Universitas Udayana tahun 2014. Data kwalitatif diukur menggunakan kuisioner. Variabel penelitian antara lain : umur, jenis kelamin, pendidikan terakhir orang tua, pendapatan orang tua, indeks masa tubuh (IMT), kegemaran mengonsumsi makanan cepat saji, pengeluaran uang saku, dan frekuensi mengosumsi makanan cepat saji.
\end{abstract}

Hasil penelitian : responden sebagian besar : a).usia 20 tahun, b).perempuan lebih banyak daripada lakilaki, c).pendidikan orang tua adalah sarjana, d). pendapatan orang tua lebih dari 5 juta rupiah/bulan, e). IMT normal, f).obesitas tipe I, g).tidak suka makanan cepat saji, h).pengeluaran uang saku mahasiswa sekitar Rp 500.000/bulan, .dan i).frekuensi mengkonsumsi makanan cepat saji 1 kali/minggu.

Simpulan : responden sebagian besar perempuan, IMT normal dan tidak suka makanan cepat saji. Kata kunci : obesitas, konsumsi makanan cepat saji, mahasiswa kedokteran, pengeluaran uang saku

\section{OVERVIEW OF CONSUMING FAST FOOD HABIT AND OBESITY IN MEDICAL STUDENTS AT UDAYANA UNIVERSITY 2014}

\section{ABSTRACT}

Background : Obesity has been occured by deposit of fat in subcutaneous and intra abdominal tissue. The prevalance of obesity in Indonesian womens were $32,9 \%$ and mens is $19,7 \%$ respectively. In general side, 
the prevalence of obesity in 18 years old adult peoples were 15,4\%. The major risk factors for obesity including lifestyle dietary changes such as consuming fast food habit.

Objective : to find out overview of consuming fast food habit and obesity in medical students.

Method : This research was cross-sectional decriptive study. The respondens were 127 medical students on $5^{\text {th }}$ semester in Udayana University on 2014. The qualitative data were be measured by questionnaires. The variables were including age, gender, general knowledge of parents, parental income monthy, body mass index (BMI), habit of consuming fast food, average outcome monlty of medical students, and daily frequency of consuming fast food.

Result : the characteristic respondens including : a) mostly 20 years old, b).women more than men, c). level education of parents were university, d). monthly parental income more than 5 million rupiah, e). BMI in normal limit, f).degree of obesity were grade I, g).inconvience consuming fast food daily, h).monthy outcome of medical students were aproximately 500.000 rupiah, and i).regular consuming fast food mostly once weekly.

Conclusion : mostly responden were women with normaly of BMI and inconvenience consuming fast food daily.

Key word : obesity, consuming fast food, medical students, outcome montly

\section{PENDAHULUAN \\ Latar Belakang}

Obesitas merupakan kondisi yang terjadi karena kelebihan lemak dalam tubuh, yang umumnya ditimbun dalam jaringan subkutan, sekitar organ tubuh dan terkadang terjadi perluasan ke dalam jaringan organnya. ${ }^{1,2} \mathrm{Hal}$ ini menjadi risiko mayor terhadap penyakit kronis yang berhubungan dengan asupan makanan seperti; Diabetes Mellitus tipe 2, penyakit jantung, hipertensi, stroke, depresi dan kanker. ${ }^{1,2,10}$ Obesitas merupakan masalah kesehatan yang dialami oleh sebagian besar masyarakat di dunia. Hal ini terlihat dari tingginya angka obesitas yang mencapai 300 juta orang dari total penduduk dunia dimana lebih dari 1 miliyar orang yang mengalami kelebihan berat badan (overweight). ${ }^{2}$ Tingginya angka tersebut terjadi di berbagai negara di dunia. Hal ini terlihat pada tahun 2007, sebanyak 33\% laki-laki dan $36 \%$ perempuan mengalami obesitas di United States. ${ }^{4}$ Jepang juga memiliki $28,6 \%$ laki-laki dan $20,6 \%$ perempuan yang mengalami obesitas. ${ }^{3}$ The Scottish Health Survey mendapatkan data nasional tentang overweight dan obesitas pada orang dewasa pada tahun 1995, 1998, 2003 dan 2008 di Scotland (Fig. 1). Data tersebut didapatkan dari pengukuran berat badan, tinggi badan, lingkar pinggang dan lingkar paha. $^{1}$

Di Indonesia, status gizi masyarakatnya dapat dilihat dari laporan Riskesdas 2013. Dari laporan
Riskesdas 2013, satus gizi dibedakan berdasarkan umur balita, 5-18 tahun, dan dewasa. Pada umur balita (<5 tahun) didapatkan status gizi gemuk sebanyak $11,9 \%$ pada tahun $2013 .{ }^{5}$ Pada umur 5-12 tahun didapatkan status gizi gemuk sebanyak $10,8 \%$ dan obesitas sebanyak 8,8\%; umur 13-15 tahun didapatkan $8,3 \%$ gemuk dan $2,5 \%$ obesitas; dan umur 16-18 tahun didapatkan 5,7\% gemuk dan $1,6 \%$ obesitas pada tahun $2013 .^{5}$ Pada umur $>18$ tahun (dewasa) didapatkan berat badan lebih 13,5\% dan obesitas $15,4 \%$ pada tahun $2013 .{ }^{5}$ Sedangkan berdasarkan jenis kelamin, didapatkan 32,9\% wanita dan $19,7 \%$ pria dewasa yang mengalami obesitas. ${ }^{5}$

Masyarakat yang mengalami obesitas makin bertambah tiap tahunnya. ${ }^{1,2,6}$ Obesitas dipengaruhi oleh beberapa faktor seperti; genetik, pola makan, tingkat aktivitas, sosial dan ekonomi. ${ }^{6} \mathrm{Di}$ antara faktor tersebut, faktor pola makan merupakan faktor dominan yang mempengaruhi obesitas. Faktor pola makan dilihat dari asupan kalori yang dikonsumsi oleh masyarakat. Pada era saat ini, masyarakat telah mengenal makanan cepat saji (fast food). Kebiasaan mengonsumsi makanan cepat saji merupakan salah satu contoh pola makan yang berubah saat ini. ${ }^{1,2}$ Makanan cepat saji mengandung nutrisi yang rendah dan kalori yang tinggi. Hal tersebut menyebabkan masyarakat mengalami status gizi yang berlebihan. 


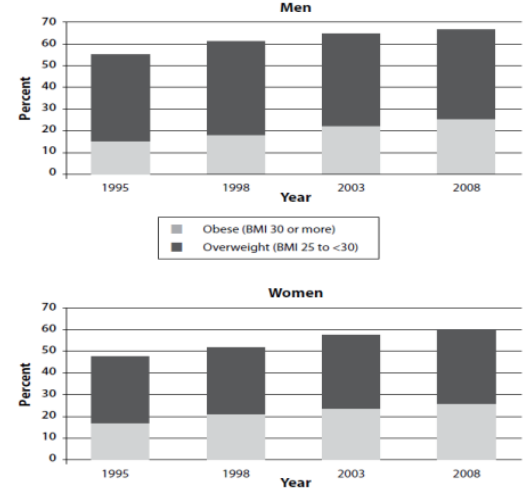

Fig. 1 Overweight dan obesitas di Scotland $2008^{1}$

\section{METODE PENELITIAN}

\section{Rancangan Penelitian}

Penelitian ini menggunakan rancangan

deksriptif cross sectional.

\section{Tempat dan Waktu Penelitian}

Penelitian ini dilakukan di Kampus Sudirman Fakultas Kedokteran Universitas Udayana, Kota Denpasar, Bali. Penelitian dilakukan mulai tanggal 20 November 2014.

\section{Populasi dan Sampel}

Populasi target yang akan digunakan pada penelitian yakni semua mahasiswa Program Studi (Prodi) Pendidikan Dokter tahun 2014. Dengan populasi terjangkau yaitu mahasiswa semester $\mathrm{V}$ Prodi Pendidikan Dokter tahun 2014. Sampel yang akan digunakan yakni semua mahasiswa semester $\mathrm{V}$ Prodi Pendidikan Dokter FK UNUD tahun 2014 yang dipilih melalui total sampling. Jumlah total sampel sebanyak 127 orang. Pemilihan sampel melalui kriteria inklusi, yakni semua mahasiswa semester V Prodi Pendidikan Dokter FK UNUD tahun 2014 yang bersedia berpatisipasi atau mendatangani informed consent. Selain kriteria inklusi, pemilihan sampel melalui kriteria eksklusi, yakni semua mahasiswa semester $\mathrm{V}$ Prodi Pendidikan Dokter FK UNUD tahun 2014 yang menolak berpatisipasi atau tidak hadir saat pelaksanaan penelitian.

\section{Cara Pengumpulan dan Analisis Data}

Pengumpulan data sosidemografi dengan pengisian kuisioner yang dilakukan secara mandiri. Pengumpulan data yang dibutuhkan dalam parameter obesitas dilakukan satu kali dengan pengukuran langsung kepada responden. Pengumpulan data tiap variabel yang dibutuhkan dalam penelitian dilakukan dengan pengisian kuisioner secara mandiri. Seluruh pengumpulan data dilakukan satu kali. Analisis data penelitian dengan deksriptif kuantitatif menggunakan komputer dengan program software SPSS 16.0.

\section{HASIL PENELITIAN}

\section{Karakteristik responden}

Pada penelitian ini, didapatkan 127 responden dari semua mahasiswa semester $\mathrm{V} F K$
UNUD tahun 2014. Seluruh responden mengisi kuisioner yang telah diberikan di ruang kuliah 4.02 Kampus Sudirman FK UNUD pada tanggal 20 November 2014. Berdasarkan data yang telah dikumpulkan melalui kuisioner dan pengukuran secara langsung, didapatkan data demografis yang terdiri atas, umur, jenis kelamin, pendidikan terakhir orang tua, dan pendapatan orang tua. Data tersebut dapat dilihat pada tabel berikut.(tabel 1 )

Dari tabel 1, didapatkan sebagian besar responden berumur 20 tahun. Dengan responden perempuan lebih banyak dari responden laki-laki. Data pendidikan terakhir orang tua didapatkan sebagian besar orang tua responden sudah menjalani pendidikan di jenjang S1. Sebagian besar pendapatan orang tua responden sebanyak lebih dari 5 juta rupiah per bulannya.

2. Karakteristik status gizi dan kebiasaan mengonsumsi makanan cepat saji responden Variabel status gizi didapatkan dari pengukuran berat badan dan tinggi badan responden. Sehingga didapatkan data Body Mass Index (BMI) tiap responden. Data BMI tersebut akan diklasifikasikan berdasarkan guideline WHO. Variabel kegemaran mengonsumsi makanan cepat saji dilihat dari pola makan responden dalam kehidupan sehari-harinya. Variabel pengeluaran uang saku diperoleh dari ratarata pengeluaran uang saku responden tiap bulannya. Variabel frekuensi konsumsi makanan cepat saji dapat dilihat dari frekuensi konsumsi makanan cepat saji yang dikonsumsi responden selama 1 minggu. (tabel 2)

Dari tabel 2, didapatkan sebagian besar status gizi responden termasuk kategori tidak obesitas dimana responden dengan kategori normal lebih banyak daripada underweight dan overweight. Sedangkan responden dengan kategori obesitas lebih banyak termasuk dalam kategori obesitas I. Berdasarkan variabel kegemaran mengonsumsi makanan cepat saji, didapatkan responden yang tidak suka mengonsumsi makanan cepat saji lebih banyak dibanding yang suka mengonsumsi makanan cepat saji. Dari variabel pengeluaran uang saku, didapatkan sebagian besar responden dengan pengeluaran uang saku per bulannya sebanyak Rp. 500.000,00 s/d Rp. $650.000,00$. Sedangkan variabel frekuensi konsumsi makanan cepat saji terdapat gambaran responden yang mengonsumsi makanan cepat saji 1 kali/minggu lebih banyak daripada yang mengonsumsi $>1$ kali/minggu.

3. Gambaran kegemaran mengonsumsi makanan cepat saji terhadap status gizi

Untuk mengetahui gambaran kebiasaan mengonsumsi makanan cepat saji terhadap status gizi responden, data ditampilkan dengan tabel sebagai berikut. (tabel 3)

Dari tabel 3, didapatkan responden dengan status gizi obesitas I dan obesitas II yang tidak suka 
konsumsi makanan cepat saji lebih banyak daripada yang suka mengonsumsi. Selain itu, responden dengan status gizi obesitas I yang memiliki pengeluaran saku tiap bulannya Rp. 500.000,00 s/d Rp. 650.000,00 lebih banyak dibandingkan dengan pengeluaran saku yang lainnya. Dan responden obese II lebih banyak menghabiskan uang saku Rp. 300.000,00 s/d Rp.
$500.000,00$ tiap bulannya. Responden obese I yang mengonsumsi makanan cepat saji 1 kali/minggu lebih banyak dibandingkan dengan lebih dari 1 kali/minggu. Sedangkan responden obese II yang mengonsumsi makanan cepat saji lebih dari 1 kali/minggu lebih banyak dibandingkan dengan 1 kali/minggu.

Tabel 1. Karakteristik Demografis Responden

\begin{tabular}{|c|c|c|}
\hline Karakteristik responden & Frekuensi & Presentase \\
\hline Umur & & \\
\hline$\bullet \quad 18$ tahun & 4 & 3,1 \\
$\bullet \quad 19$ tahun & 15 & 11,8 \\
$\bullet \quad 20$ tahun & 90 & 70,9 \\
$\bullet \quad>20$ tahun & 18 & 14,2 \\
\hline Jenis kelamin & & \\
\hline$\bullet \quad$ Laki-laki & 34 & 26,6 \\
$\bullet \quad$ Perempuan & 93 & 73,2 \\
\hline Pendidikan terakhir orang tua & 1 & \\
\hline$\quad$ SD & 18 & 8 \\
$\bullet \quad$ SMA & 60 & 14,2 \\
$\bullet \quad$ S2 & 22 & 47,2 \\
$\bullet \quad$ S3 & 7 & 17,3 \\
- D4 & 7 & 5,5 \\
\hline Pendapatan orang tua & & 5,5 \\
\hline < 1juta rupiah & 4 & \\
$\bullet \quad>5$ juta-2,5 juta rupiah & 16 & 3,1 \\
\hline
\end{tabular}

Tabel 2. Gambaran status gizi, kegemaran mengonsumsi makanan cepat saji, pengeluaran uang saku dan frekuensi konsumsi makanan cepat saji

\begin{tabular}{|c|c|c|}
\hline & Frekuensi & Presentase \\
\hline \multicolumn{3}{|l|}{ Status gizi } \\
\hline - Underweight & 16 & 12,6 \\
\hline - Normal & 71 & 55,9 \\
\hline - Overweight & 19 & 15 \\
\hline - Obese I & 18 & 14,2 \\
\hline - $\quad$ Obese II & 3 & 2,4 \\
\hline \multicolumn{3}{|l|}{ Kegemaran mengonsumsi makanan cepat saji } \\
\hline - Suka & 49 & 38,6 \\
\hline - Tidak suka & 77 & 60,6 \\
\hline \multicolumn{3}{|l|}{ Pengeluaran uang saku } \\
\hline - $\quad$ Rp. $200.000,00$ s/d Rp. $300.000,00$ & 21 & 16,5 \\
\hline - $\quad$ Rp. $300.000,00$ s/d Rp. $500.000,00$ & 47 & 37 \\
\hline - $\quad$ Rp. $500.000,00$ s/d Rp. $650.000,00$ & 59 & 46,5 \\
\hline \multicolumn{3}{|l|}{ Frekuensi konsumsi makanan cepat saji } \\
\hline • $1 \mathrm{kali} / \mathrm{minggu}$ & 86 & 70,5 \\
\hline - $\quad>1 \mathrm{kali} / \mathrm{minggu}$ & 36 & 29,5 \\
\hline
\end{tabular}


Tabel 3. Gambaran kebiasaan mengonsumsi makanan cepat saji terhadap status gizi

\begin{tabular}{|c|c|c|c|c|c|c|}
\hline \multirow[t]{2}{*}{ Karaktersitik } & \multicolumn{5}{|c|}{ Status gizi } & \\
\hline & $\begin{array}{c}\text { Under } \\
\text { Weight }\end{array}$ & Normal & $\begin{array}{c}\text { Over } \\
\text { weight }\end{array}$ & Obese I & $\begin{array}{c}\text { Obese } \\
\text { II }\end{array}$ & \\
\hline \multicolumn{7}{|c|}{$\begin{array}{l}\text { Kegemaran mengonsumsi makanan cepat } \\
\text { saji }\end{array}$} \\
\hline • Tidak & 9 & 43 & 10 & 12 & 3 & 77 \\
\hline - $\quad \mathrm{Ya}$ & 7 & 28 & 8 & 6 & 0 & 49 \\
\hline \multicolumn{7}{|l|}{ Pengeluaran uang saku tiap bulan } \\
\hline - $\quad \mathrm{Rp} 200.000,00-\mathrm{Rp} 300.000,00$ & 3 & 14 & 3 & 1 & 0 & 21 \\
\hline - $\quad \operatorname{Rp} 300.000-R p 500.000,00$ & 5 & 27 & 8 & 4 & 3 & 47 \\
\hline - $\quad \operatorname{Rp} 500.000-\operatorname{Rp} 650.000$ & 8 & 30 & 8 & 13 & 0 & 59 \\
\hline \multicolumn{7}{|l|}{$\begin{array}{l}\text { Frekuensi mengonsumsi makanan cepat } \\
\text { saji tiap minggu }\end{array}$} \\
\hline • $1 \mathrm{kali} / \mathrm{minggu}$ & 12 & 42 & 14 & 17 & 1 & 86 \\
\hline \multirow[t]{2}{*}{ - $\quad>1 \mathrm{kali} / \mathrm{minggu}$} & 2 & 26 & 5 & 1 & 2 & 36 \\
\hline & 16 & 71 & 18 & 18 & 3 & 127 \\
\hline
\end{tabular}

Tabel 4. Distribusi pengeluaran uang saku dan kegemaran mengonsumsi makanan cepat saji terhadap status gizi

\begin{tabular}{|c|c|c|c|c|c|c|}
\hline $\begin{array}{l}\text { Pengeluaran uang saku tiap bulan } \\
\text { dan kegemaran mengonsumsi } \\
\text { makanan cepat saji }\end{array}$ & $\begin{array}{c}\text { Under } \\
\text { weight }\end{array}$ & Normal & $\begin{array}{c}\text { Over } \\
\text { weight }\end{array}$ & Obese I & $\begin{array}{c}\text { Obese } \\
\text { II }\end{array}$ & \\
\cline { 2 - 7 } Rp 200.000,00 - Rp 300.000,00 & & & & & & \\
\hline$\bullet \quad$ Ya & 2 & 9 & 1 & 1 & 0 & 13 \\
$\bullet \quad$ Tidak & 1 & 5 & 2 & 0 & 0 & 8 \\
\hline Rp 300.000,00 - Rp 500.000,00 & & & & & & \\
\hline$\quad$ Ya & 1 & 9 & 2 & 1 & 0 & 13 \\
$\bullet \quad$ Tidak & 4 & 18 & 5 & 3 & 3 & 33 \\
\hline Rp 500.000,00 - Rp 650.000,00 & 4 & 10 & 5 & 4 & 0 & 23 \\
\hline$\quad$ Ya & 4 & 20 & 3 & 9 & 0 & 36 \\
\hline$\quad$ Tidak & 16 & 71 & 18 & 18 & 3 & \\
\hline
\end{tabular}

Tabel 5. Distribusi pengeluaran uang saku dan frekuensi konsumsi makanan cepat saji terhadap status gizi

\begin{tabular}{|c|c|c|c|c|c|c|}
\hline \multirow{2}{*}{$\begin{array}{c}\text { Pengeluaran uang saku/ bulan } \\
\text { dan frekuensi konsumsi } \\
\text { makanan cepat saji/minggu }\end{array}$} & \multicolumn{5}{|c|}{ Status gizi } & \\
\hline & $\begin{array}{l}\text { Under } \\
\text { weight }\end{array}$ & Normal & $\begin{array}{c}\text { Over } \\
\text { Weight }\end{array}$ & Obese I & Obese II & \\
\hline \multicolumn{7}{|l|}{ Rp 200.000,00-Rp 300.000,00 } \\
\hline - $1 \mathrm{kali} / \mathrm{minggu}$ & 3 & 8 & 1 & 1 & 0 & 13 \\
\hline - $\quad>1$ kali/minggu & 0 & 5 & 2 & 0 & 0 & 7 \\
\hline \multicolumn{7}{|l|}{ Rp 300.000,00-Rp 500.000,00 } \\
\hline - $1 \mathrm{kali} / \mathrm{minggu}$ & 3 & 17 & 6 & 4 & 1 & 31 \\
\hline - $\quad>1$ kali/minggu & 1 & 9 & 2 & 0 & 2 & 14 \\
\hline \multicolumn{7}{|l|}{ Rp 500.000,00-Rp 650.000,00 } \\
\hline - $1 \mathrm{kali} / \mathrm{minggu}$ & 6 & 17 & 7 & 12 & 0 & 42 \\
\hline - $\quad>1$ kali/minggu & 1 & 12 & 1 & 1 & 0 & 15 \\
\hline
\end{tabular}


4. Gambaran pengeluaran uang saku tiap bulan dan kegemaran mengonsumsi makanan cepat saji terhadap status gizi

Untuk mengetahui gambaran pengeluaran uang saku tiap bulan dan kegemaran mengonsumsi makanan cepat saji terhadap status gizi, dapat dilihat dari tabel 4.

5. Gambaran pengeluaran uang saku tiap bulan dan frekuensi konsumsi makanan cepat saji tiap minggu terhadap status gizi

Untuk mengetahui gambaran pengeluaran uang saku tiap bulan dan frekuensi konsumsi makanan cepat saji tiap minggu terhadap status gizi, dapat dilihat dari tabel 5 .

\section{PEMBAHASAN}

Penelitian ini menggambarkan kebiasaan mengonsumsi makanan cepat saji terhadap obesitas pada mahasiswa Prodi Kedokteran Umum FK UNUD semester V tahun 2014. Mahasiswa Prodi Kedokteran Umum FK UNUD semester $V$ tahun 2014 yang mengalami obesitas sebanyak 21 responden $(16,8 \%)$ dan yang tidak mengalami obesitas sebanyak 106 responden $(83,5 \%)$. Penelitian ini menggunakan 3 faktor untuk mengukur kebiasaan mengonsumsi makanan cepat saji pada responden. Faktor-faktor itu yakni gemar mengonsumsi makanan cepat saji, pengeluaran uang saku tiap bulan dan frekuensi mengonsumsi makanan cepat saji dalam 1 minggu. ${ }^{8}$ Ketiga faktor tersebut merupakan faktor-faktor yang berperan dalam peningkatan prevalensi obesitas pada masyarakat.

Faktor kegemaran dan frekuensi mengonsumsi makanan cepat saji dalam 1 minggu merupakan faktor yang dapat menggambarkan perubahan pola makan masyarakat. ${ }^{8}$ Waktu yang singkat dan terlihat lebih enak menyebabkan makanan cepat saji sangat digemari. ${ }^{8}$ Faktor uang saku menjadi salah satu faktor yang mempengaruhi prevalensi obesitas saat ini. Makanan cepat saji menjadi salah satu makanan pilihan mahasiswa yang hidup merantau (tinggal di kos-kosan atau asrama). Selain mudah, biaya makanan cepat saji dapat dijangkau oleh kalangan mahasiswa. ${ }^{8}$ Sehingga mereka akan memilih makanan cepat saji dibandingkan makanan lainnya. Hal inilah yang menyebabkan peneliti menggunakan ketiga faktor tersebut untuk mengukur kebiasaan mengonsumsi makanan cepat saji pada mahasiswa Prodi Kedokteran Umum FK UNUD semester $\mathrm{V}$ tahun 2014.

Pada hasil penelitian, didapatkan mahasiswa Prodi Kedokteran Umum FK UNUD semester $V$ yang mengalami obese I dan obese /I lebih banyak pada kelompok yang tidak suka makanan cepat saji. Berdasarkan pengukuran faktor uang saku yang dimiliki oleh mahasiswa tiap bulannya, mahasiswa yang mengalami obese I lebih banyak menghabiskan uang saku Rp. 500.000 s/d Rp. 650.000,00 tiap bulannya dan mahasiswa yang mengalami obese II lebih banyak menghabiskan uang saku Rp 300.000,00Rp 500.000,00 dalam 1 bulan. Sedangkan hasil pengukuran berdasarkan faktor frekuensi mengonsumsi makanan cepat saji dalam 1 minggu, didapatkan mahasiswa Prodi Kedokteran Umum FK UNUD semester $\mathrm{V}$ yang termasuk kategori obese I paling banyak pada kelompok yang sering mengonsumsi makanan cepat saji 1 kali/minggu. Sedangkan yang termasuk kategori obese /I paling banyak pada kelompok yang mengonsumsi makanan cepat saji lebih dari 1 kali/minggu.

Pada kelompok mahasiswa yang mengalami obese I menghabiskan uang saku Rp 500.000,00 s/d Rp $650.000,00$ tiap bulannya, didapatkan mahasiswa yang tidak suka mengonsumsi makanan cepat saji lebih banyak dibandingkan yang gemar mengosnumsi. Hal ini didapatkan juga pada mahasiswa yang mengalami obese II pada kelompok yang menghabiskan uang saku Rp 300.000 s/d Rp 500.000,00 tiap bulannya. Pada kelompok mahasiswa yang menghabiskan uang saku Rp 500.000,00 s/d Rp 650.000,00 tiap bulannya dan frekuensi mengonsumsi makanan cepat saji 1 kali/minggu lebih banyak mengalami obese $I$. Sedangkan kelompok yang menghabiskan uang saku Rp 300.000,00 s/d Rp 500.000,00 tiap bulan dan frekuensi mengonsumsi makanan cepat saji lebih dari $1 \mathrm{kali} /$ minggu lebih banyak obese II.

Hasil penelitian ini menunjukkan gambaran kebiasaan mengonsumsi makanan cepat saji terhadap obesitas pada mahasiswa Prodi Kedokteran Umum FK UNUD semester $V$ tahun 2014. Dari penelitian didapatkan beberapa mahasiswa mengalami obese I dan II. Hal ini menunjukkan bahwa masyarakat yang mengalami obesitas tidak hanya kalangan dewasa tua. Saat ini obesitas dapat dialami seluruh kalangan masyarakat. ${ }^{1,5} \mathrm{Hal}$ ini terjadi akibat pola hidup kurang gerak (sedentary), perubahan pola makan dan tingkat aktivitas. ${ }^{9,11,12}$ Penelitian ini hanya mengurai tentang kebiasaan mengonsumsi makanan cepat saji yang menjadi salah satu perubahan pola makan yang terjadi di masyarakat. Kebiasaan mengonsumsi makanan cepat saji diukur dari 3 faktor yang dominan. Faktorfaktor tersebut antara lain; faktor ekonomi, faktor kegemaran dan faktor frekuensi mengonsumsi makanan cepat saji dalam 1 minggu. ${ }^{8,15}$

Faktor ekonomi merupakan salah satu faktor dominan dalam kebiasaan mengonsumsi makanan cepat saji. Hal tersebut disebabkan oleh 2 hal, yaitu tingkat ekonomi yang dimiliki dan harga makanan cepat saji yang terjangkau. 8,13,14 Pengukuran tingkat ekonomi pada mahasiswa dapat dilihat dari pengeluaran uang saku yang digunakan untuk memenuhi kebutuhan pangan tiap bulannya. Mahasiswa yang memiliki hidup dengan tingkat ekonomi menengah hingga tinggi memiliki resiko yang 
lebih tinggi mengalami obesitas dibandingkan dengan tingkat ekonomi kurang. Pada penelitian ini, didapatkan gambaran dimana mahasiswa pengeluaran uang saku diatas Rp 300.000,00 tiap bulan mengalami obese I dan obese II.

Selain faktor ekonomi, kebiasaan mengonsumsi makanan cepat saji dapat dilihat dari faktor kegemaran dan frekuensi mengonsumsi makanan cepat saji. Pada penelitian ini, didapatkan sebagian besar mahasiswa Prodi Kedokteran Umum FK UNUD semester $V$ yang mengalami obesitas tidak gemar dan mengonsumsi makanan cepat saji 1 kali/minggu. Hasil pengukuran ini menunjukkan hasil yang berbeda dengan paradigma yang ada di masyarakat. Hal ini disebabkan faktor penyebab obesitas lainnya selain faktor kebiasaan mengonsumsi makanan cepat saji. Faktor-faktor tersebut antara lain faktor pola aktivitas, faktor genetik, faktor sosial ekonomi, dan lain-lain.,5-10 Faktor-faktor tersebut memiliki keterkaitan satu dengan yang lainnya. Hal tersebut terlihat dari peningkatan angka obesitas saat ini. Beberapa penelitian telah dilakukan untuk mencari tahu penyebab tingginya angka obesitas. Dari penelitian tersebut, didapatkan adanya kombinasi faktor makanan cepat saji dan pola hidup kurang bergerak (sedentary life)., ${ }^{9,11}$ Sehingga faktor yang mempengaruhi obesitas pada mahasiswa Prodi Kedokteran Umum FK UNUD semester V tahun 2014 tidak hanya dari kebiasaan mengonsumsi makanan cepat saji. Sehingga perlu dilakukan penelitian lebih lanjut untuk mencari tahu faktor lainnya yang mempengaruhi obesitas pada mahasiswa Prodi Kedokteran Umum FK UNUD semester V tahun 2014.

\section{PENUTUP}

\section{Kesimpulan}

Dari penelitian tentang gambaran kebiasaan mengonsumsi makanan cepat saji terhadap obesitas mahasiswa Prodi Kedokteran Umum FK UNUD semester V tahun 2014, didapatkan kesimpulan sebagai berikut:

1. Mahasiswa Prodi Kedokteran Umum FK UNUD semester $\mathrm{V}$ tahun 2014 memiliki karakteristik status gizi underweight $12,6 \%$, normal $55,9 \%$, overweight $15 \%$, obese | $4,2 \%$, dan obese II $2,4 \%$.

2. Mahasiswa yang mengalami obese I dan obese Il lebih banyak tidak menyukai makanan cepat saji daripada yang menyukai makanan cepat saji.

3. Mahasiswa yang mengalami obese I dan obese II lebih banyak menghabiskan uang saku tiap bulannya diatas Rp 300.000,00.

4. Mahasiswa yang mengalami obese I dan obese II lebih banyak mengonsumsi makanan cepat saji hanya 1 kali/minggu dibandingkan dengan mahasiswa yang mengonsumsi makanan cepat saji lebih dari 1 kali/minggu

\section{Saran}

Dari penelitian ini, peneliti memberikan saran sebagai berikut:

1. Perlu dilakukan penelitian lebih lanjut untuk mengetahui hubungan antara kebiasaan mengonsumsi makanan cepat saji dengan prevalensi obesitas.

2. Perlu dilakukan penelitian yang membahas hubungan faktor-faktor dengan prevalensi obesitas.

3. Mahasiswa perlu mendapatkan edukasi mengenai makanan yang sehat dan bergizi untuk menurunkan resiko terjadinya obesitas pada diri mereka masing-masing.

\section{DAFTAR PUSTAKA}

Anonim, A National Clinical Guideline Management of Obesity. Scottish Intercolligiate Guidelines Network. 2010.

Puska P, Nishida C, Porter D. Obesity and Overweight. World Health Organization. 2003.

Fukue, Natsuko. TV Gets Fickle Fans Flocking to Fads to Shed Fat. Japan Times. 2010.

4Bessesen DH. Update on Obesity. J Clin Endocrinol Metab 93 (6): 2027-34. 2008.

Riskesdas. Status Gizi. Riskesdas 2013: 249-70. 2013

Mallik Vasanti S, Willet Walter C, Hu Frank B. Global Obesity: Trends, Risk Factors, and Policy Implications. Macmillan Publisher: 1-18. 2012

De Vogli Roberto, Kouvonen Anne, Gimeno David. The Influence of Market Deregulation on Fast Food Consumption and Body Mass Index: a Cross-National Time Series Analysis. Bull World Health Organ 92: 99107A. 2014

Seo Hyun-sun, Lee Soo-Kyung, Nam Soyoung. Factors Influencing Fast Food Consumption Behavioral of Middle School Student in Seoul: an Application of Theory of Planned behaviors. Nutrition Research and Practice 5(2): 169-178. 2011

Mushtaq Muhammad Umair, Gull Sibgha, Mustagh Komal, Shahid Ubeera, Shad Mushtaq Ahmad, Akram Javed. Dietary Behaviors, Physical Activity and Sedentary Lifestyle Associated with Overweight and Obesity, and Their Socio-demographic Correlates, among Pakistani Primary School Children. Mushtaq et 
al. International Journal of Behavioral Nutrition and Physical Activity, 8: 130.2011

Davis Brennan, Carpenter Christopher. Proximity of Fast-Food Restaurant to Schools and Adolescent Obesity. American Journal of Public Health vol 99 no 3: 505-510. 2009

Jacobs David R. Fast Food and Sedentary Lifestyle: a Combination that Leads to Obesity. Am J Clin Nutr 83: 189-90. 2006

Vilchis-Gill Jenny, Galvan-Portillo Marcia, KlunderKlunder Miguel, Cruz Miguel, Flores-Huerta Samuel. Food Habits, Physical Activities and Sedentary Lifestyle of Eutrophic and Obese School Children: a Case-control Study. Vilchis-Gil et al BMC Public Health 15: 124. 2015

Drewnowski Adam, Darmon Nicole. The Economics of Obesity: Dietary Energy and Energy Cost. Am J Clin Nutr 82: 265S-73S. 2005

Grossman Michael, Mocan Naci. Economic Aspect of Obesity. University of Chigago Press: 17-34. 2011

Anderson Beth, Rafferty Ann P. Lyon-Callo Sarah, Fussman Christopher, Imes Gwendoline. Fast-Food Consumption and Obesity Among Michigan Adults. Preventing Chronic Disease Public Health Research, Practice, and Policy vol.8 no.4: 1-11. 2011 